MT. VERNON, OHIO AREA LINEAMENT ANALYSIS

Prepared by

Shafer Exploration Company, Inc.

Columbus, Ohio

For

Thurlow Weed \& Associates, Inc.

Columbus, Ohio

Work Performed Under Contract No.: AC21-78MC08386

December 1978

For

U.S. Department of Energy

Office of Fossil Energy

Morgantown Energy Technology Center

Morgantown, West Virginia

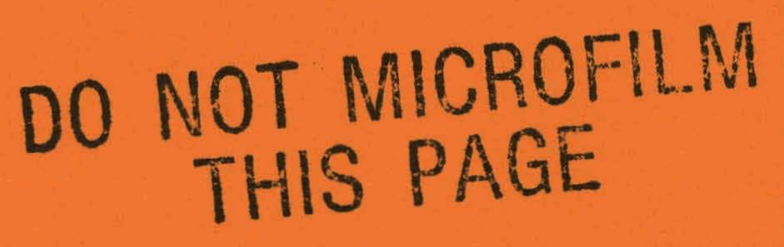

MASTER

\author{
TECHNICAL INFORMATION CENTER \\ OFFICE OF SCIENTIFIC AND TECHNICAL INFORMATION \\ UNITED STATES DEPARTMENT OF ENERGY
}




\section{DISCLAIMER}

This report was prepared as an account of work sponsored by an agency of the United States Government. Neither the United States Government nor any agency Thereof, nor any of their employees, makes any warranty, express or implied, or assumes any legal liability or responsibility for the accuracy, completeness, or usefulness of any information, apparatus, product, or process disclosed, or represents that its use would not infringe privately owned rights. Reference herein to any specific commercial product, process, or service by trade name, trademark, manufacturer, or otherwise does not necessarily constitute or imply its endorsement, recommendation, or favoring by the United States Government or any agency thereof. The views and opinions of authors expressed herein do not necessarily state or reflect those of the United States Government or any agency thereof. 


\section{DISCLAIMER}

Portions of this document may be illegible in electronic image products. Images are produced from the best available original document. 


\title{
MT. VERNON, OHIO AREA LINEAMENT ANALYSIS
}

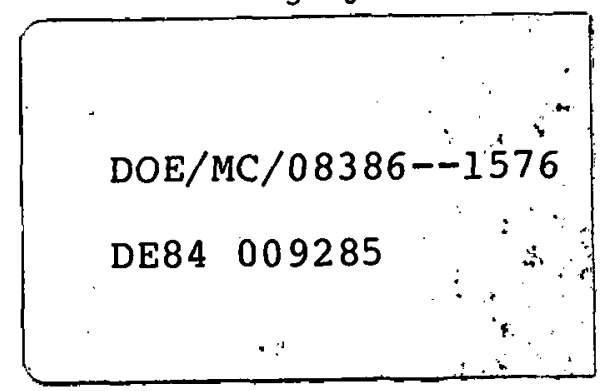

\author{
Prepared by \\ Shafer Exploration Company, Inc. \\ 1395 East Dublin Granville Road \\ Columbus, Ohio 43229
}

\author{
For \\ Thurlow Weed \& Associates, Inc. \\ 1765 Edgemont Drive \\ Columbus, Ohio 43212 \\ Work Performed Under Contract No. AC21-78MC08386
}

December 1978

For

U.S. Department of Energy

Office of Fossil Energy

Morgantown Energy Technology Center

P.0. Box 880

Morgantown, West Virginia 26.505

\section{DISCLAIMER}

This report was prepared as an account of work sponsored by an agency of the United States Government. Neither the United States Government nor any agency thereof, nor any of their employees, makes any warranty, expres3 or implicd, or assumes any legal liability or responsibility for the accuracy, completeness, or usefulness of any information, apparatus, product, or process disclosed, or represents that its use would not infringe privately owned rights. Reference herein to any specific commercial product, process, or service by trade name, trademark, manufacturer, or otherwise does not necessarily constitute or imply its endorsement, recommendation, or favoring by. the United States Government or any agency thereof. The views and opinions of authors expressed herein do not necessarily state or reflect those of the United States Government or any agency thereof.

\section{MASTER}

DISTRIBUTIOA OF TMIS DOCUMENT IS UNIMITED 


\section{THIS PAGE \\ WAS INTENTIONALLY \\ LEFT BLANK}


Introduction $\ldots \ldots \ldots \ldots \ldots \ldots \ldots \ldots \ldots \ldots \ldots$

Exploration Rationale $\ldots \ldots \ldots \ldots \ldots \ldots \ldots \ldots \ldots$

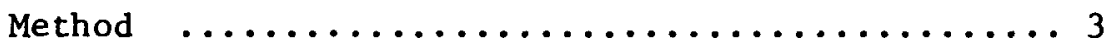

Results of Investigation-1 ............ 5

Results of Investigation-2 $\ldots \ldots \ldots \ldots \ldots \ldots \ldots$

Figure 1 Lineament Rosette $\ldots \ldots \ldots \ldots \ldots \ldots \ldots 7$

Results of Investigation-3 $\ldots \ldots \ldots \ldots \ldots \ldots$

Results of Investigation-4 .............. 10

Next Step Rationale $\ldots \ldots \ldots \ldots \ldots \ldots \ldots \ldots \ldots$

Figure 2 (Subsurface Hypothesis) $\ldots \ldots \ldots \ldots \ldots \ldots 12$

Recommendations $\ldots \ldots \ldots \ldots \ldots \ldots \ldots \ldots \ldots \ldots \ldots \ldots \ldots$ 


\section{.}

INTRODUCTION

This subject analysis was performed by Shafer Exploration Company, Inc., of Columbus, Ohio, W.E. Shafer, Geologist, under a purchase order subpart of the Thurlow Weed and Associates, Inc., Contract Number EW-78-C-21-8386, (October, 1978), with the United States Department of Energy (US-DOE) to investigate the Devonian Shale (gas) potential in the Mt. Vernon, Ohio, area.

The details of the contract overview and purpose may be read in other pertinent reports within the contract report system.

The subject lineament analysis subroutine was designed as an exploration technique to essentially locate a new (contract) well to test the Devonian Shale for (free flow) hydrocarbon accumulations.

On 2 October 1978, first notice was received to consider and prepare the lineament analysis program.

On 4 October 1978, the work order was awarded; procedure, image, and map organization commenced.

On 24 October 1978, pertinent LANDSAT images ( $1: 250,000$ Scale) were ordered from the EROS Data Center, Sioux Falls, South Dakota.

Various decisions consequent to contract time constraints were made, in series, to proceed on analytical program with available library data while EROS Data Center products were in process. No sacrifice in essential analysis quality is belleved to have been made. 


\section{INTroouctrDONNOT MICROFILM THIS PAGE}

This subject analysis is a purchase order subpart of the Thurlow Weed and Associates, Inc., Contract Number EW-78-C-21-8386, (October, 1978), with the United Stdtes Department of Energy (US-DOE) to investigate the Devonian Shale (gas) potential in the Mt. Vernon, Ohio area.

The details of the contract overview and purpose may be read in other pertinent reports within the contract report system.

The subject lineament analysis subroutine was designgd as an exploration techn to essentially locate a new (contract) well to test the Devonian shale for free flow) hydrocarblen accumulations.

Dotober 1978, first notice was recejted to consider and prepare the linamalys program.

20 October 1978, the work deder tas awarded; procedure, image, and map o 10.

$\sum_{12}^{\infty}$ October 1978

the EROS Data Center, Sigux Falls, Sdyth Dakota.

$\infty$ Various analysis prodycts were either received by order or were in investigator library and only the high altitude photograph pipducts are, at this time, still in EROS processing (9 Defember 1978). Various decisidns consequent to contract time constraints were mode, in series, to proceed on analytical program with available library data whife EROS Data Center products were in prockss. No sacrifice in essential analysis quality is believed to have been made. The high altitude EROS photo produgts, when received and analyzed, shall be acknowledged by supplementary analysis letter to this report.

\section{DO NOT MICROFILM THIS PAGE}




\section{EXPLORATION RATIONALE}

The exploration rationale assumes the following conditions.

1. Natural, geomorphic lineaments observed at altitude represent siginificant fractured, jointed, and/or faulted bedrock zones.

2. Natural geomorphic lineament zones may extend in depth below the bedrock.

3. Natural geomorphic lineament zones may contain (free flowing) hydrocarbons at depth and therefore constitute (free flowing) hydrocarbon reservoirs.

4. Natural geomorphic lineament zones may be discontinuous horizontally and vertically and may be sealed, in part, in the two dimensions sufficiently to cause a trap (or traps) to free flowing hydrocarbon migration.

3. Natural geomorphic lineament zones are often expressed through glacial overburden through a variety of depositional, errosional and botanical expressions.

The US-DOE contract exploration effort prior to drilling operations was expressly designed to (1) find (free flowing) natural gas in the Devonial Shale fracture reservoir(s), if any: and (2) prove the aforementioned exploration rationale and total exploration technique(s). 


\section{METHOD}

The library of maps and images, ie. in any final process combination leading to final photography, presented an array of same area view and were analyzed in descending order of scale.

1. The Physical World.Map, National Geographic, 1975; 1" : 760 Miles (Equator)

2. United States of America, Mosaic from ERTS-1, NASA, 1974, 1": 80 Miles

3. Same as above, Sheet $\mathrm{K}, 1974,1^{\prime \prime}: 16$ Miles -

4. Ohio, East Half; LANDSAT-2, 8 March 1973, 6 Scene Mosaic, EROS Data Center, MSS5, $1^{\prime \prime}: 14$ Miles \pm

5. Mt. Vernon, Ohio area, LANDSAT-2, 8 March 1973, MSS4, 5 \& 7, Single Scene, Color (False) Composit, 1" : 4 Miles.

6. Mt. Vernon, Ohio area, same as above except MSS5, Black and White only.

7. Ohio, USGS, 1977, Shaded Relief with Contours, Drainage and Culture, 1" : 8 Miles.

8. Same as above, 1970, Shaded Relief with Drainage Only; 1 " : 8 Miles.

9. Ohio and adjacent areas, USA Map Service, 1969, with Contours, Drainage and Culture, $1^{\prime \prime}: 4$ Miles.

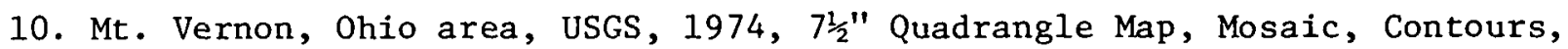
Drainage, and Culture, $1^{\prime \prime}: 2000^{\prime}$ ( $1^{\prime \prime}: .38$ Miles).

The major regional lineaments were identified, reviewed and first traced on the aforementioned Item 4 image and then progressively identified and traced with increasing detail on the subsequent images and maps of lesser scale.

The final mapping manuscript was placed on the USGS $1^{\prime \prime}: 2000^{\prime}$ scale map. The northwest trending major regional lineament zone of specific interest has its apparent origin in the Appalachian Mountain front in the area of Roanoke, Virginia. This lineament zone passes through Mt. Vernon, Ohio. Other subregional and local lineaments in various orientations were also mapped. Sufficient mapping was done 
upon a subjective, first view basis to organize the lineaments and detail the Mt. Vernon area of interest. Only sufficient detail was mapped to provide lineament organization. The $1^{\prime \prime}: 2000^{\prime}$ map manuscript was then transferred to a like base map for this management report presentation. This approach has provided several potential well locations at the intersections of lineaments. At this point we recognize an alternate hypothesis that represents major lineaments leak hydrocarbons and may be, therefore hydrocarbon deficient.

The hypotheses upon which this program proceeds represents that natural geomorphic lineament zones may contain (free flowing) hydrocarbons at depth, and therefore, constitute (free flowing) hydrocarbon reservoirs wherein gas may also be trapped-in-reservoir. (See previously stated rationale, Items 1-5, this report). 


\section{RESULTS OF INVESTIGATION-I}

Several lineament intersections in the specific area of interest are evident and indicated by a yellow "high-1ight" circle on the Lineament Analysis Map. The greatest number of separate, evident lineament intersections with strong support lineament evidence, would appear to be the most prospective well site locations. These locations have been prioritized in subjective rank, 1 (best) to 11 , on the attached map. The locations are limited to selections generally within land areas under oil and gas lease by the operator-contractor.

WORD OF CAUTION: Although investigative procedure, based upon a scientific rationale and method have been applied, the reader should also note that the business of oil and gas discovery is a risky business and little or no recovery of hydrocarbon may occur with or without the content knowledge of this report. 
LINEAMENT ROSETTE, MT. VERNON, OHIO AREA, FIGURE 1

The azimuth of all of the lineaments indicated on the attached map were measured and arranged in related ten degree bearing groups. The rosette illustrates the primary and then lesser lineation orientation in obvious order.

$$
\begin{array}{ll}
\text { Primary: } & \mathrm{N} 30^{\circ}-40^{\circ} \mathrm{W} . \\
\text { Secondary: } & \mathrm{N} 70^{\circ}-80^{\circ} \mathrm{E}
\end{array}
$$

l'his statistical device, if found to be valid by test, may be used to visualize average incipient fracture directions within rock units. Also, the relative direction and propagation success that an induced fracture might develop in the (open) borehole may be better understood. Finally, the rosette may be a valuable element in a formula to determine direction and distances to proposed, related offset wells.

The funded exploration program shall determine the validity of the applied exploration tools, e.g. LANDSA' imagery, U-2 style photographs, topographic maps and surface geologic measurements in the area. 
TOTAL NUMBER OF LINEAMENTS PER $10^{\circ}$ AZIMUTH (FIGURE 1)

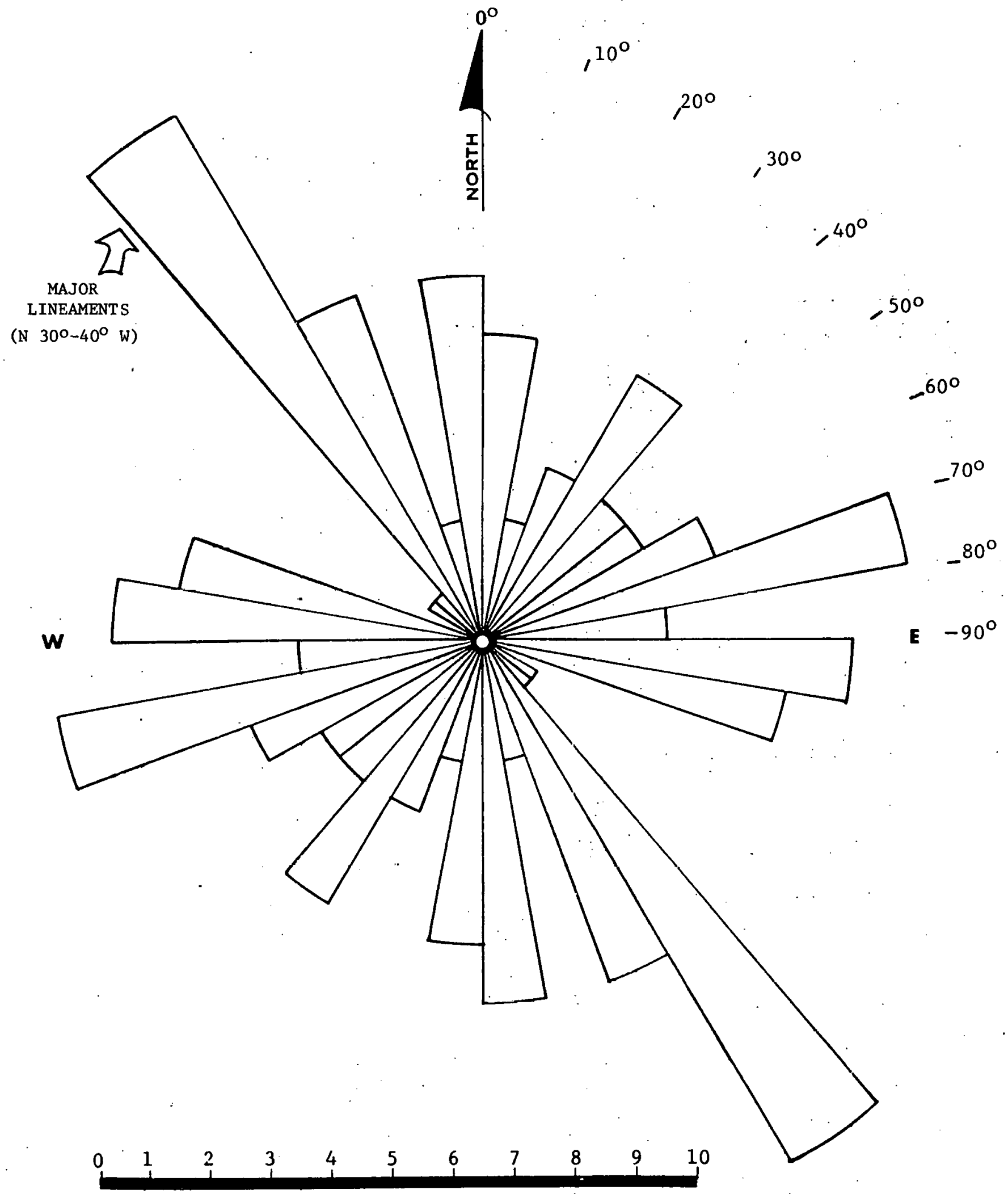

NUMBER OF . LINEAMENTS 


\section{RESULTS OF INVESTIGATION -3}

The major lineament hereinafter called "Roanoke lineament zone" could be traced intermittently and successively from: :

1. Appalachian Mountain front, Roanoke, Virginia area

2. Cottageville, West Virginia area

3. Newark, Ohio area

4. Mt. Vernon, Ohio area

5. Frederickstown, Ohio area

The gross Roanoke lineament zone is arcuate NW. The local area pattern appears nearly straight line NW. The zone looses continuity as it passes into glacial overburden. A loss of identity appears to be accute in the Junction City-Thornville, Ohio area where glacial outwash and end moraine crosses the lineament projection at a high angle.

The view of the Roanoke lineament zone evidence within the remainder of affected glacial overburden is hereinafter rationalized.

1. The lineament zone was actively and differentially erroded (planes of weakenss) during preglacial time.

2. The dynamic glaclal ice movement further enhanced preglacial drainage valleys, particularly in valleys oriented with ice movement direction.

3. Glacial sediments settled by differential compaction into preglacial drainage.

4. Glacial outwash water followed the lower clevation of old, preglarial drainage systems.

5. Drainage within the glacial area generally aligns with drainage outside of the glacial area.

6. Floral reflectance (tones) indigineous to either valley buttoms or ridge tops are obvious. 
7. Ridge trend lines usually parallel valley trend lines.

Gross lineament continuity is dependent upon both aligned ridges and valleys.

In the Newark to Mt. Vernon to Frederickstown zone area, the lineament is traced by the North Fork (of the Licking River) and Kokosing River (North). Other physiographic features are also evident illustrating other lineament orientations of major apparent subregional importance. The area of interest is subdivided into local lineaments or lineament segments essentially upon the drainage and associated slope or ridge patterns identified on the very small scale, $1^{\prime \prime}: 2000^{\prime}$ topographic map(s). These minute details are associated with and relate to the gross physiographic features identified on the large scale LANDSAT images as well as the large scale physiographic maps of the state.

We may gain new appreciation for the old prospector who used, with some success, considerable "Creekology" when making his well locations.

It is this writer's opinion that many more fracture (joint) features exist than are usually uncovered, noticed, or mapped, and that several echelons of joint sets are superimposed within any given area. Incipient oriented joints within descrete 1ithic blocks should be expected. The map illustrating results which attach to this report simply illustrate the more obvious joint pattern probabilities. 
RESULTS OF INVESTIGATION-4

The Western Hemisphere macro-lineament view is important and relates to the interior Ohio "microview" illustrated on the attached map.

\section{OBSERVATIONS}

(a) Lineaments - Mid-Atlantic Ridge

$$
\begin{aligned}
& \mathrm{N} 10^{\circ}-20^{\circ} \mathrm{W} \\
& \mathrm{N} 40^{\circ}-50^{\circ} \mathrm{W} \\
& \mathrm{N} 40^{\circ}-50^{\circ} \mathrm{W}
\end{aligned}
$$

(b) Lineaments - Bermuda Rise

(c) Lineaments - Continental Slope \& Shelf (Cape Fear area to New York area)

(d) Lineaments - Eastern Region Area

(Cape Hateras foint \& Albemarlè Sound)

Arcuate

$\mathrm{N} 30^{\circ}-50^{\circ} \mathrm{W}$

(North Carolina Coast to Mansfield, Ohio area)

$\mathrm{N} 40^{\circ}-50^{\circ} \mathrm{W}$

The image mosaic, E'R'S-1, Eastern United States, Sheet $\mathrm{K}$, illustrates the pronounced lineament from Cape Hateras Point and Albemarle Sound (Chowan Arm), North Carolina coast through the Appalachian Mountains in the Waynesboro, Virginia area and through the Powhatan Point-Moundsville area on the Ohio River. An evident bifurcation occurs as the lineament is traced in oh1o. The south, more ubvious limb, proceeds through Coshocton, Ohio area and the north Iimb proceeds through the Mohicanville Reservoir area, between Wooster and Mansfield, Ohio. The northern limb lineament may be traced with difficulty into lower Michigan and perhaps further to the northwest.

The Bouguer Gravity Anomaly Map of the United States, (AGU, 1964, 1" = 40 Miles) illustrates zones of gravity change in the alignment from Cape Hateras Point, North Carolina to Lake-of-the-Woods, Ontario.

Other sub-parallel regional lineaments can also be observed radiating from, or possibly through the Appalachian Mountain chain. A local, dominant lineament system compatible with the regional lineament zone orientation is apparent in the Mt. Vernon, Ohio area. 


\section{NEXT STEP RATIONALE}

(FIGURE 2)

The joint zones are, in essence, assumed to be basement controlled. The joint zones are assumed to be nearly vertical and continue at depth in discontinuous pattern or, in any event, healed sufficiently to form descrete traps in zones of potential hydrocarbon accumulations. Surface field geologic observations with compass and certainly by a drill test with oriented view of the borehole shall tend to confirm or deny the next step exploration rationale important to shale gas exploration or any low porosity or permeability reservoir. 


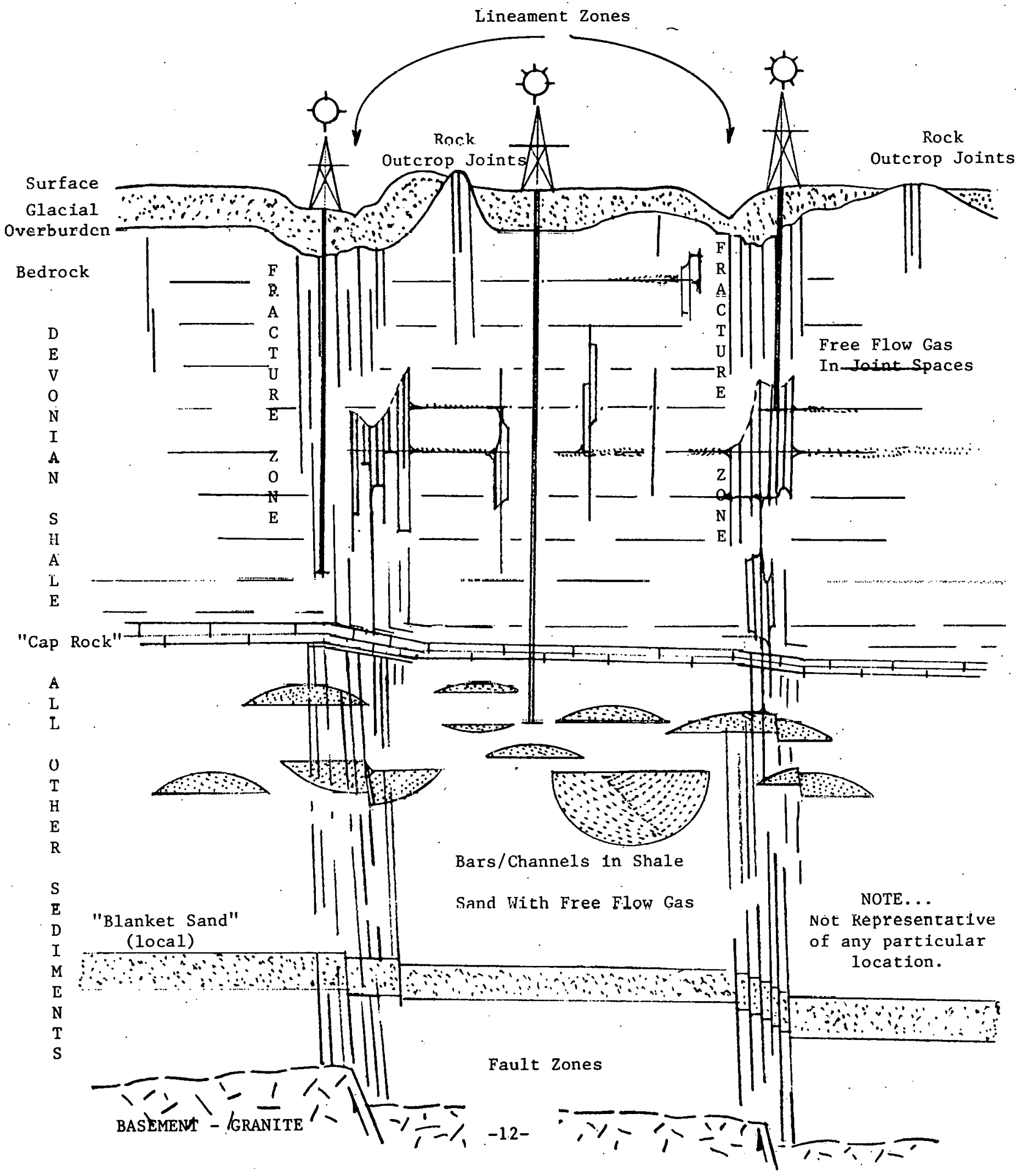




\section{RECOMMENDATIONS}

1. Drill a test hole(s) for gas in shale fractures through the local, potential Devonian Shale gas zones at one (or more) of the lineament intersections indicated on the attached map.

2. Run the following downhole geophysical surveys along with the suite of surveys in program:

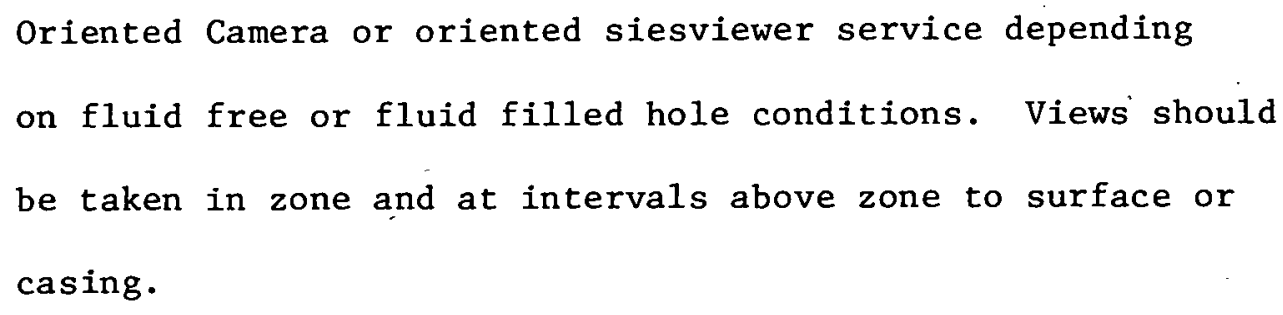

These surveys shall allow a view and understanding of downhole fractures, if any, and fracture orientation. This direct evidence will be compared to surface lineament orientation.

3. Field check geologic evidence (and map location) strike and dip of a random sample of fractures in bedrock exposures.

4. Correlate all geophysical and geologic evidence to prove, or disprove, the prugram operating hypothesis. 
